\title{
MIR34A pre-miRNA
}

National Cancer Institute

\section{Source}

National Cancer Institute. MIR34A pre-miRNA. NCI Thesaurus. Code C95833.

MIR34A pre-miRNA (110 bases) is encoded by the human MIR34A gene. This

oligonucleotide is involved in mRNA stability. 